\title{
MATERNAL RESULTS FROM PLANNED HOME BIRTHS ASSISTED BY NURSES FROM THE HANAMI TEAM IN THE SOUTH OF BRAZIL, 2002-2012
}

\author{
Joyce Green Koettker1, Odaléa Maria Brüggemann², Roxana Knobel ${ }^{3}$
}

\begin{abstract}
${ }^{1}$ Ph.D. in Nursing. Professor, Programa de Pós-Graduação em Enfermagem, Universidade Federal de Santa Catarina (PEN/UFSC). Grantfunded scholar of the Coordination for the Improvement of Higher Education Personnel (CAPES). Florianópolis, Santa Catarina, Brazil. Email: joycegreenk@yahoo.com.br

2 Ph.D. in Obstetrics and Gynecology. Professor, Department of Nursing, PEN/UFSC. National Council for Scientific and Technological Development (CNPq) researcher. Florianópolis, Santa Catarina, Brazil. Email: odalea.bruggemann@ufsc.br

${ }^{3}$ Ph.D. in Obstetrics and Gynecology. Professor, Department of Gynecology and Obstetrics, Faculty of Medicine, UFSC. Florianópolis, Santa Catarina, Brazil. Email: knobel@uol.com.br
\end{abstract}

\begin{abstract}
Objective: described the maternal results of the care with planned home births provided by the Hanami Team in $2002-2012$.

Method: this transversal study It includes home and hospital births (212). Descriptive analysis was undertaken, with CI 95\%, using the SAS/9.1.3 software.

Results: the rate of amniotomy was 9.9\% (CI 95\% 5.9-13.9), of episiotomy was 0.5\% (CI 95\% 0.5-1.5), the amniotic fluid remained clear in 95.2\% (CI 95\% 92.4-98), there was no change in fetal heartbeat in $94.3 \%$ (CI 95\% 92-96.6). The vaginal tears perineal trauma were exclusively of first degree (64.7\%; CI 95\% 57.8-71.6) and second degree (7.0\%; CI 95\% 3.4-10.8), it being the case that almost half did not need suturing (46.8\%; CI 95\% 41.1-52.6). The rate of transfer to hospital was 7.4\%, all these cases occurring during labor (CI 95\% 3.8 - 11.0). The rate of cesareans in the sample was $9.9 \%$.

Conclusions: the women assisted at home undergo few interventions. Rates of complications and transfers to hospital for obstetric reasons were low.

DESCRIPTORS: Home childbirth. Natural childbirth. Humanizing delivery. Term birth. Obstetric nursing.

\section{RESULTADOS MATERNOS DOS PARTOS DOMICILIARES PLANEJADOS ASSISTIDOS POR ENFERMEIRAS DA EQUIPE HANAMI NO SUL DO BRASIL, 2002-2012}

\section{RESUMO}

Objetivo: descrever os resultados maternos da assistência ao parto domiciliar planejado pela Equipe Hanami, de 2002/2012.

Método: estudo transversal. Foram incluídos os partos ocorridos no domicílio e no hospital (212), no referido período. Foi realizada análise descritiva com IC a 95\%, no SAS/9.1.3.

Resultados: a taxa de amniotomia foi 9,9\% (IC 95\% 5,9-13,9), de episiotomia 0,5\% (IC95\% 0,5-1,5), o líquido amniótico permaneceu claro em 95,2\% (IC95\% 92,4-98), não houve alteração dos batimentos cardíacos fetais em 94,3\% (IC95\% 92-96,6). As lacerações vaginais foram exclusivamente de primeiro grau $(64,7 \%$; IC $95 \% 57,8-71,6)$ e de segundo grau $(7,0 \%$; IC $95 \% 3,4-10,8)$, sendo que praticamente a metade não necessitou de sutura (46,8\%; IC95\% 41,1-52,6). A taxa de transferência foi de 7,4\%, sendo todas durante o trabalho de parto (IC95\% 3,8-11,0). A taxa de cesárea da amostra foi 9,9\%.

Conclusão: as mulheres assistidas no domicílio são submetidas a poucas intervenções. As intercorrências e transferências obstétricas são baixas.

DESCRITORES: Parto domiciliar. Parto normal. Parto humanizado. Nascimento a termo. Enfermagem obstétrica. 


\title{
RESULTADOS MATERNOS DE LA ASISTENCIA AL PARTO DOMICILIÁRIO PLANEADO ATENDIDOS POR ENFERMERAS DEL EQUIPO HANAMI EN SUL DEL BRASIL, 2002-2012
}

\begin{abstract}
RESUMEN
Objetivo: describe resultados maternos de asistencia al parto domiciliario planeado por el Equipo Hanami, 2002/2012.

Método: estudio transversal. Fueron inclusos partos en domicilio y en hospital (212). El análisis descriptivo fue realizado en SAS/9.1.3., con IC 95\%.

Resultados: la tasa de amniotomía fue 9,9\% (IC 95\% 5,9-13,9), de episiotomía 0,5\% (IC95\% 0,5-1,5), el líquido amniótico permaneció claro en 95,2\% (IC 95\% 92,4 a 98), no hubo alteración en la frecuencia cardíaca fetal en 94,3\% (IC 95\% 92-96,6). Laceraciones vaginales fueron de primer grado (64,7\%; IC 95\%: 57,8 a 71,6) y de segundo (7,0\%; IC 95\% 3.4 a 10.8), y casi la mitad no necesitó sutura (46,8\%; IC 95\%: 41,152,6). La tasa de transferencia fue de 7,4\% (IC 95\%: 3,8 a 11,0). La tasa de cesáreas en la muestra fue de 9,9\%.

Conclusión: las mujeres que reciben asistencia en el domicilio son sometidas a pocas intervenciones, complicaciones obstétricas y las transferencias son bajas.
\end{abstract}

DESCRIPTORES: Parto domiciliário. Parto normal. Parto humanizado. Nacimiento a término. Enfermería obstétrica.

\section{INTRODUCTION}

Worldwide, various studies have been published regarding maternal and neonatal results arising from assistance with home birth. Among these, one stands out - a systematic review from the Cochrane Library. ${ }^{1}$ Practically all confirm that there is a lower rate of obstetric interventions in home births. ${ }^{2-7}$

The choice of this place to give birth is recommended by the World Health Organization (WHO), so long as the assistance is undertaken by a qualified professional with a transfer plan for cases in which this is indicated. ${ }^{8}$ Physicians, nurse midwives and midwives are considered to be qualified professionals. ${ }^{9}$

Brazilian studies have indicated that the practice of giving birth at home, planned and assisted by a qualified professional and with a transfer plan has been the preferred choice for some Brazilian women. ${ }^{10-11}$ Internationally, studies have demonstrated an increase in the number of women seeking to give birth at home; ${ }^{12-13}$ a fact which may result from women's greater satisfaction with the experience of giving birth at home. ${ }^{14-16}$

In the Brazilian context, quantitative studies on this issue have been few in number and with small samples; they have, however, shown good maternal results. In the literature, there is a rate of maternal transfer in labor between $11.0 \%$ and $20.0 \% .{ }^{10-11}$

There is a good scientific basis that good obstetric practices help to promote better obstetric and neonatal results, and that - on the other hand - unnecessary interventions can be harmful for the binomial's health. ${ }^{17}$ In Brazil, the general rate of cesareans in hospital births $(2011-2012)$ was of $55.4 \%,{ }^{18}$ considered one of the highest rates in the world; regarding home births, cesareans were between 5.7\% and $9.0 \%{ }^{10-11}$ Other obstetric interventions also seem to have an important reduction in care provided in the home, such as episiotomies, in which the rate was from $0.0 \%$ to $1.0 \%$ in home births..$^{10-11}$ In contrast, among women of normal obstetric risk cared for in hospital, the rate was $56.1 \% .{ }^{17}$ Home births seem to be more associated with the use of good practices, such as the presence and promotion of freedom to choose companions, positions in which to give birth, and encouragement for early skin-to-skin contact and breast-feeding. ${ }^{10-11,19}$

Considering that, in Brazil, this mode of care continues to be poorly accepted by health professionals, in spite of the good international indicators (low rates of transfer to hospital, of complications and of interventions), it becomes necessary to invest in the production of Brazilian data such that it may be possible to critically evaluate the results of this practice, the complications and the indications for transfer of women to a health institution during this type of attendance. As a result, this investigation aims to describe the results of care in home births planned by the Hanami Team between 2002 and 2012 .

\section{METHOD}

This is a descriptive study of the attendances to planned home births, in Santa Catarina, undertaken in the period $2002-2012$ by the Hanami Team. This team is made up of five obstetric and neonatal nurses who provide care privately during pregnancy, the prepartum period, birth and the postpartum period. The first contact of the pregnant women/ couples and their family members with the team takes place in the monthly meeting termed "Getting to know the Hanami Team", which aims to present the way of working and the attendance protocol, 
and to clarify doubts. In accordance with the protocol, only women who are undertaking the prenatal checkup and who have not presented comorbidities up to the point when labor begins are included. ${ }^{20}$ In the $30^{\text {th }}$ week of pregnancy, the Team makes the first contact in order to present the work contract and initiate the bonds of trust. The second meeting takes place in the 33rd week, and the weekly prepartum home care begin in the $36^{\text {th }}$ week. During these consultations, the obstetric evaluation and the "sensitive prenatal check-up" are undertaken, with a view to assessing the environment/context in which the woman/family is inserted, including the socioeconomic, cultural and psychological aspects. It is at this point that the health institution and professional who will attend the pregnant woman in the event of transfer being indicated are defined, it being the case that the family will go to the previously-chosen health institution in its own car or in the car of one of the nurses when the women are in labor but without risk to their lives. In cases of emergency and/or complications, the Ambulance Service (SAMU) is actioned to carry out the transport, with the appropriate safety. It is stipulated that one of the nurses of the Team will accompany the intra-hospital attendance. ${ }^{20}$

The pregnant woman, upon identifying the first signs of childbirth, will make telephone contact with one of the Team's nurses, who drives to the home. In cases of labor, a further two nurses go to the locale, taking the material for attending the birth and for basic life support (oxygen, an aspirator, fluid therapy, medications, catheters, etc.) in order to deal with complications which might affect the woman and/or the newborn (NB). ${ }^{20}$

During the attendance to the labor and birth, besides the continuous obstetric evaluation, various nonpharmacological techniques for pain relief are also undertaken. Among those used most, one finds: taking a shower or bath, massage of the lumbosacral region, use of the birth ball and moxabustion. ${ }^{21}$

After the birth, the NB's skin-to-skin contact with the mother is begun and breast-feeding is encouraged. After, respecting the neonate's first hour of life, $1 \mathrm{mg}$ of vitamin $\mathrm{K}$ is administered intramuscularly, and the NB's complete physical examination, and the red reflex test are carried out. The puerpera is accompanied during the clinical periods which follow: placental expulsion and the Greenberg period. The team remains in the locale until the mother and NB are stable. The team provides assistance to the binomial until the $10^{\text {th }}$ day postpartum, consultations being undertaken on the $1^{\text {st }}, 3^{\text {rd }}, 4^{\text {th }}, 7^{\text {th }}$ and $10^{\text {th }}$ days postpartum, and on the 15th day of life, if the NB has not reached birth weight. In the first postpartum visit, (24 hours of life of the NB), the nurse undertakes the pulse oximetry screening, and the family receives guidance for undertaking the Neonatal Triage Test and that of Evoked Otoacoustic Emissions. Besides this, guidance is provided regarding exclusive breast-feeding up to the $6^{\text {th }}$ month, and regarding vaccinations recommended by the Ministry of Health. ${ }^{20}$

This study includes all the women assisted by the Team during the period studied, that is, those who gave birth at home and those who initiated labor at home, but who were transferred to hospital. As a result, the sample includes all the vaginal births which took place at home and the hospital births, as well as the cesareans resulting from maternal transfer; there being, therefore, no exclusion criteria.

The data from the women assisted at home were collected from the respective medical records, filled out and filed by the nurses of the Team. The data of the women who were transferred were obtained from the records found in the Personal Child Health Record and from the information found in the consultations in the postpartum period.

The variables analyzed were sociodemographic and obstetric data from the pregnancy (Age: years complete on the day of birth; Educational level: junior high school incomplete/complete, senior high school incomplete/complete, higher education complete/complete, postgraduate incomplete/ complete; Occupation: student, housewife or other; Medical care in the prenatal period: one, two, three, four, five, six or more than six; Nursing care in the prepartum period: One, two, three, four, five, six, or more than six; Previous births: none, one, two, three, four, five or more; Locale of the previous births: at home, at the normal birth center, hospital or other; and Need for transfer in the prenatal period: yes or no); obstetric data on the labor (fetal heart beats: normal, bradycardia and tachycardia; Rupturing of membranes: spontaneous, artificial; Color of amniotic fluid: clear or meconial; and Indication for transfer of the parturient woman: an arrest of the progression of the fetal descent, an arrest of cervical dilatation, nonreassuring fetal cardiac frequency, need for analgesia, cephalopelvic disproportion, fetus in the occipito-sacral position or other); obstetric data from the birth (childbirth position: squatting, genupectoral and semi-sitting in the water, squatting on the birthing stool; squatting, semi-sitting and 
genupectoral out of the water; kneeling, standing, lying on the side (also known as the Sims position), in any position; Episiotomy: yes or no; Perineal conditions: no perineal trauma, laceration of the first, second, third, or fourth degree; and Perineoplasty: yes or no); obstetric data from the immediate postpartum period (Obstetric complications in the stage of the expulsion of the placenta: hemorrhage, expulsion of placenta delayed/prolonged or other); and of birth in the institution (Birth route: normal birth, or with forceps or ventouse, birth with analgesia, birth with analgesia and forceps or ventouse and cesarean section).

The data were collected through a standardized questionnaire and were later reviewed, codified and typed using the Epi Info program, version 2008. Descriptive analysis was undertaken (relative and descriptive frequency), with a confidence interval of $95 \%$, using the SAS software version 9.1.3.

The research protocol was approved by the Research Ethics Committee of the Federal University of Santa Catarina on 14/12/2009, under certificate N. 552, with the expansion of the sample approved on $22 / 10 / 2012$. All of the aspects which involve the study are in accordance with Resolution N. 196/96 of the Brazilian National Health Council, and Resolution N. 466 of $12^{\text {th }}$ December 2012.22

\section{RESULTS}

During the 11 years of attendance, there was a total of 212 cases accompanied, of whom 187 gave birth at home (Figure 1). The majority of the women were aged between 24 and 28 years old, had completed higher education, and undertook paid activity (Table 1).

Table 1 - Sociodemographic and obstetric characteristics of the women assisted by the Hanami Team, Santa Catarina, 2002 - 2012. $(n=212)$

\begin{tabular}{|c|c|c|c|}
\hline Variables & n & $\%$ & CI $95 \%$ \\
\hline Age (mean) $(n=205)$ & \multicolumn{2}{|c|}{29.2 years (SD: 4.8 ) } & \\
\hline $19-23$ & 21 & 10.2 & $6.1-14.4$ \\
\hline $24-28$ & 79 & 38.5 & $31.9-45.2$ \\
\hline $29-33$ & 71 & 34.6 & $28.1-41.1$ \\
\hline $34-34$ & 24 & 11.7 & $7.3-16.1$ \\
\hline $39-44$ & 10 & 4.9 & $1.9-7.9$ \\
\hline \multicolumn{4}{|l|}{ Educational level $(n=200)$} \\
\hline High school incomplete/complete & 19 & 9.5 & $5.5-13.6$ \\
\hline Higher education incomplete & 56 & 28.1 & $21.9-34.2$ \\
\hline Higher education complete & 93 & 46.7 & $39.8-53.6$ \\
\hline Postgraduate - incomplete/complete & 26 & 13.1 & $8.4-17.7$ \\
\hline Other & 5 & 2.5 & $0.3-4.7$ \\
\hline Data not given & 1 & & \\
\hline \multicolumn{4}{|l|}{ Occupation $(n=209)$} \\
\hline Student & 35 & 17.3 & $12.2-22.5$ \\
\hline Housewife & 17 & 8.4 & $4.7-12.2$ \\
\hline Paid activity & 150 & 74.3 & $68.3-80.2$ \\
\hline Data not provided & 7 & & \\
\hline \multicolumn{4}{|l|}{ Medical care in the prenatal period (177) } \\
\hline$\leq 5$ & 27 & 16.5 & $11.0-21.9$ \\
\hline$\geq 6$ & 137 & 83.5 & $78.1-89.0$ \\
\hline Data not provided & 13 & & \\
\hline \multicolumn{4}{|l|}{ Nursing care in the prepartum period (184) } \\
\hline$\leq 3$ & 97 & 52.7 & $45.5-59.9$ \\
\hline$\geq 4$ & 85 & 46.2 & $39.0-53.4$ \\
\hline None $^{*}$ & 2 & 1.1 & $0.0-2.6$ \\
\hline
\end{tabular}

Referred by the prenatal physician, after confirmation of normal risk pregnancy.

In the first year of attendance, 2002, only one woman was assisted at home; the highest number of home births was concentrated in 2009 - 2011 (Figure 1). 


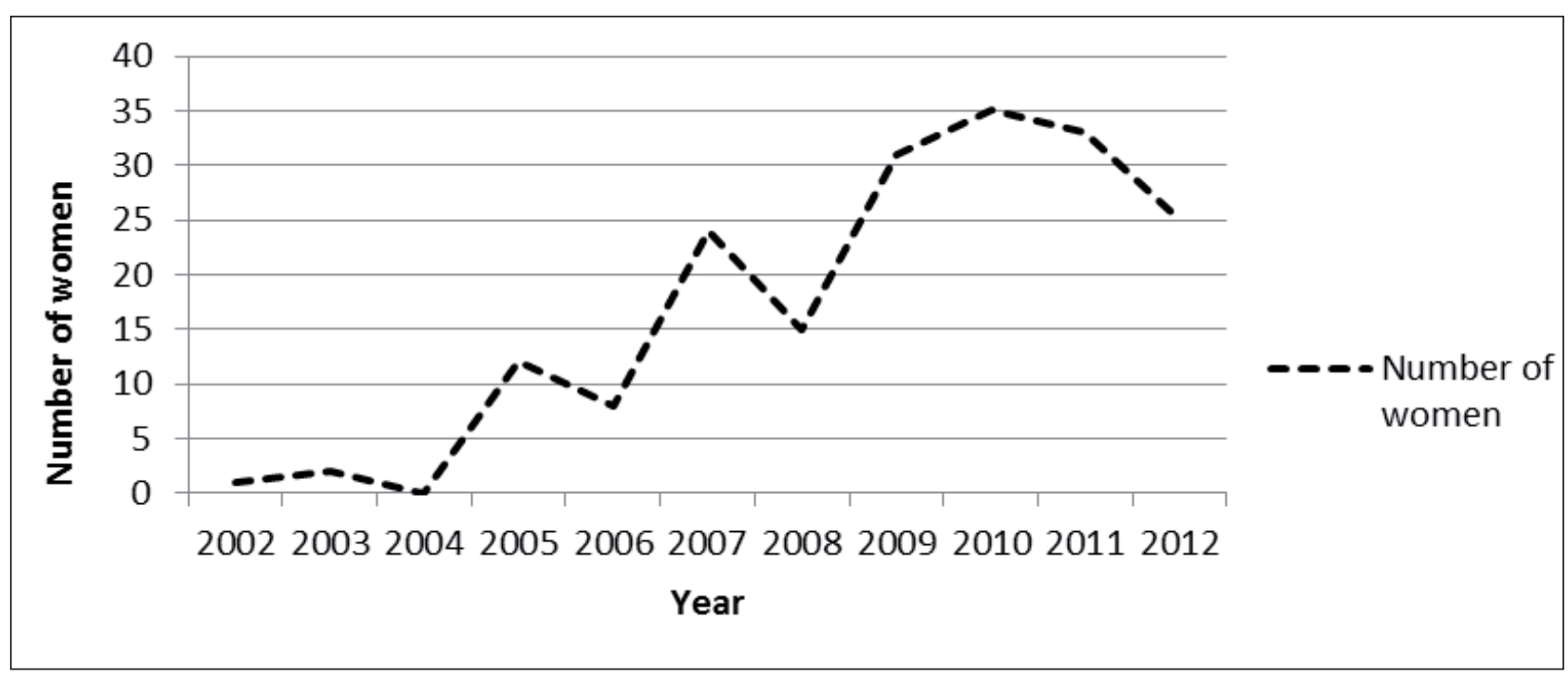

Figure 1 - Planned home births assisted by the Hanami Team. Santa Catarina, 2002 - 2012. (n=187)

The obstetric results are presented in Table 2. One can observe that the majority of those attended were primiparous, although the increase in the attendance of multiparous women is evidenced in Figure 2; likewise, the high number of women who opted for a water birth is visible (Figure 3).

It is emphasized that episiotomy was undertaken in only one parturient woman, and that the rate of intact perineum was $27.3 \%$. In relation to the perineal lacerations, none were of the third or fourth degree, all being exclusively of the first or second degree, it being the case that of the women who presented perineal laceration, almost half did not need perineal suturing. The fetal heart beat remained normal in most of the cases monitored.

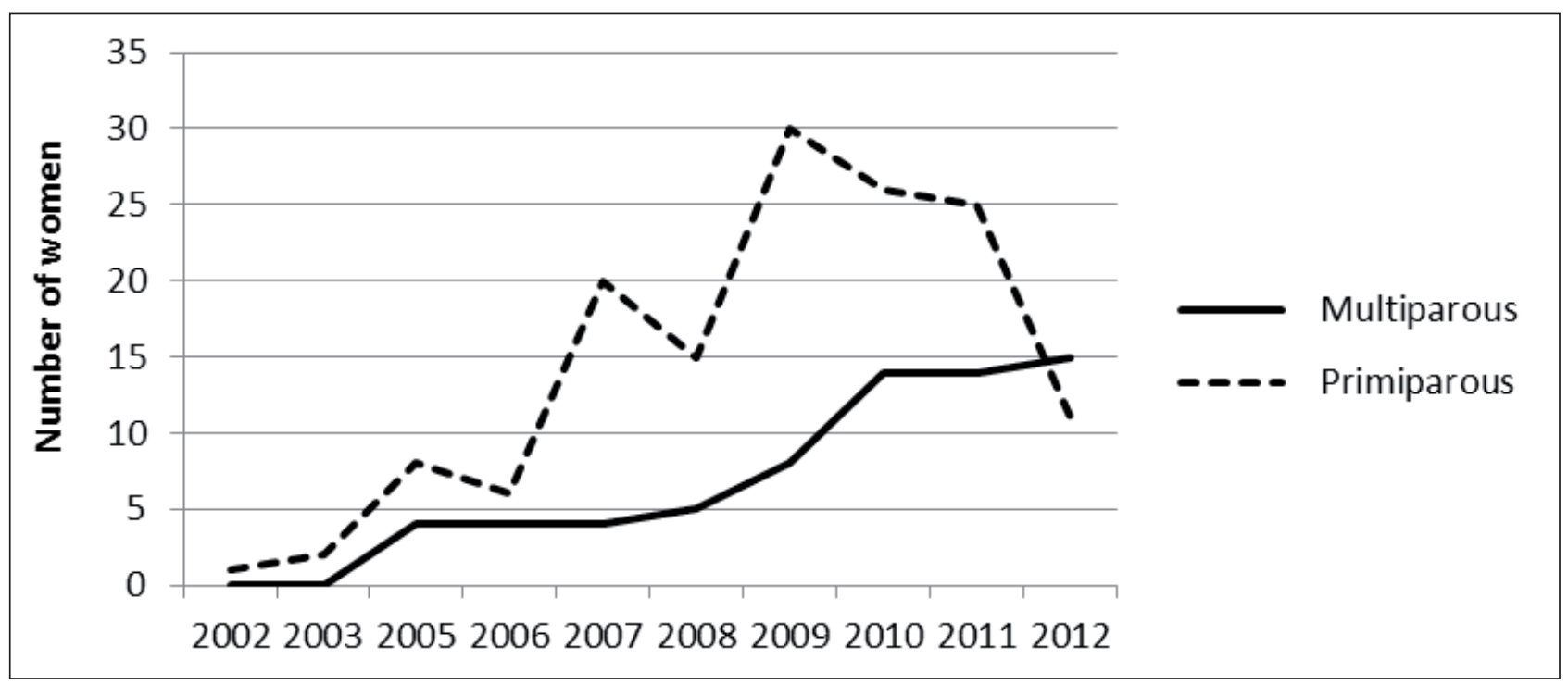

Figure 2 - Parity of the women assisted by the Hanami Team. Santa Catarina, 2002-2012. (n=212) 


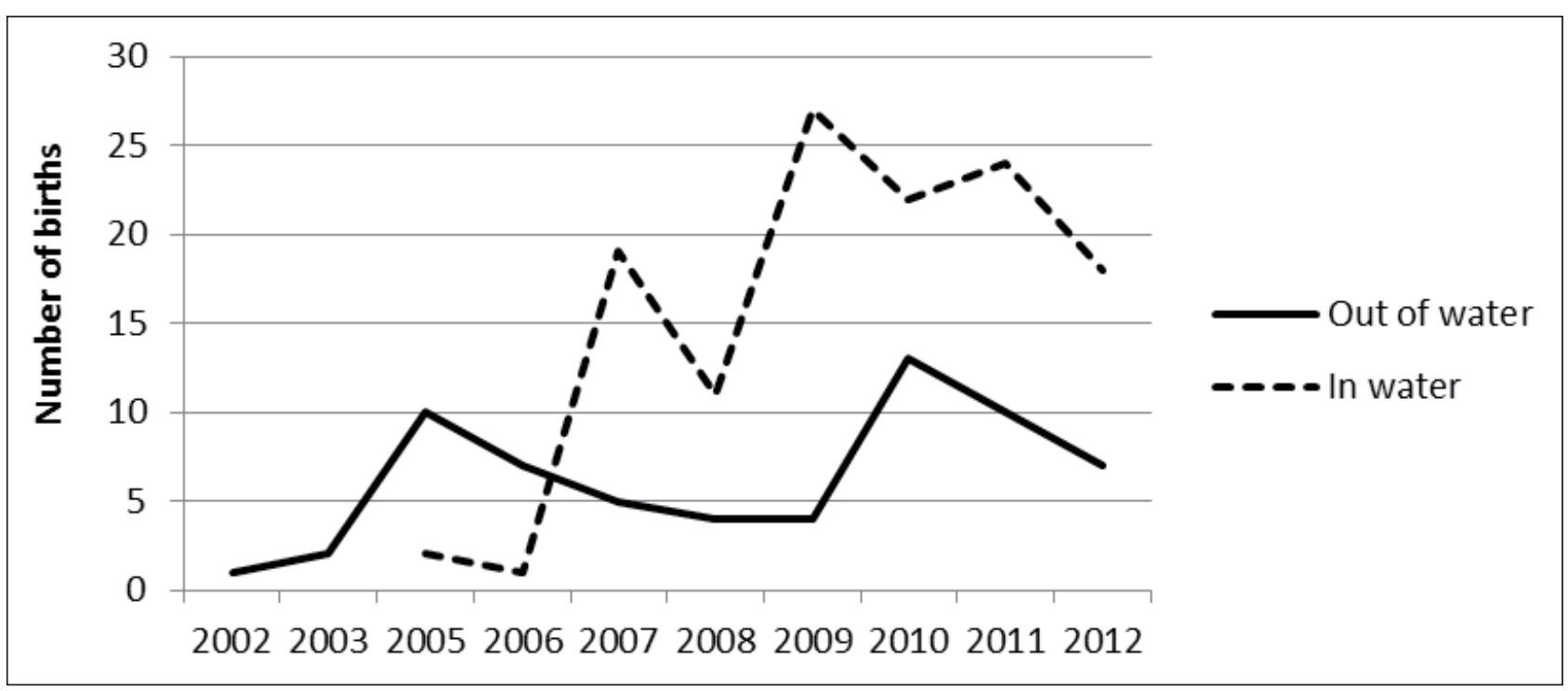

Figure 3 - Distribution of the home births assisted in and out of water by the Hanami Team. Santa Catarina, 2002-2012. $(\mathrm{n}=187)$

The rate of maternal transfer during the pregnancy was $4.7 \%$, and in labor was $7.4 \%$, there being no transfer after the birth. Among the causes of maternal transfer during labor, emphasis is placed on: arrest of cervical dilatation and arrest of fetal descent.
Of the women's complications in the postpartum period, the most frequent was delayed or prolonged expulsion of the placenta; however, no puerperal woman needed to be transferred because of this complication.

Table 2 - Distribution of the variables for attendance in the home, from the prenatal care to the postpartum period, by the Hanami Team, in Santa Catarina, 2002 - 2012. (n=212)

\begin{tabular}{lrrr}
\hline Variable & $\mathbf{n}$ & \% & \multicolumn{1}{c}{ CI 95\% } \\
\hline Parity & & & \\
$\quad$ Primiparous & 144 & 67.9 & $61.6-74.2$ \\
$\quad$ Multiparous & 68 & 32.1 & $25.8-38.4$ \\
Previous home birth & 22 & 10.4 & $6.3-14.5$ \\
Transfers in the prenatal period & 10 & 4.7 & $1.9-7.5$ \\
Normal fetal heartbeat (n=202) & 190 & 94.0 & $90.7-97.3$ \\
Amniotomy (n=202) & 20 & 9.9 & $5.9-13.9$ \\
Clear amniotic fluid (n=202) & 192 & 95.0 & $92.0-98$ \\
Transfers during labor (n=202) & 15 & 7.4 & $3.8-11.0$ \\
Birth at home (n=187) & & & \\
$\quad$ Out of water & 64 & 34.2 & $27.4-41.0$ \\
$\quad$ In water & 123 & 65.8 & $59.0-72.6$ \\
Perineal conditions (n= 187) & & & \\
$\quad$ Intact perineum & 51 & 27.3 & $20.9-33.7$ \\
$\quad$ Episiotomy & 1 & 0.5 & $0.0-1.5$ \\
Perineal laceration (n=135) & 135 & 72.2 & $65.8-78.6$ \\
$\quad$ Laceration - first degree & 119 & 72.1 & $65.6-78.6$ \\
$\quad$ Laceration - second degree & 13 & 7.9 & $4.0-11.8$ \\
$\quad$ Laceration - third or fourth degree & 0 & 0 & \\
$\quad$ Perineal suturing (of those who had laceration) & 98 & 59.4 & $52.3-66.5$ \\
$\quad$ Data not provided & 3 & &
\end{tabular}




\begin{tabular}{lrrr}
\hline Variable & $\mathbf{n}$ & \% & \multicolumn{1}{c}{ CI 95\% } \\
\hline Hemorrhage & 12 & 6.4 & $2.9-9.9$ \\
$\quad$ Others & 6 & 3.2 & $0.7-5.7$ \\
Means of childbirth in the hospital $(\mathrm{n}=25)$ & & & \\
$\quad$ Cesarean & 21 & 84.0 & $69.6-98.4$ \\
$\quad$ Vaginal birth & 4 & 16.0 & $1.6-30.4$ \\
\hline
\end{tabular}

\section{DISCUSSION}

The results indicate that the number of women who choose to give birth at home through the Hanami Team is increasing, and that complications, the need for transfer and cesarean are low. The majority of the findings are similar to those already published in studies undertaken in Brazil and other, developed, countries. ${ }^{4,6,10,12-13,23-26}$

One of the limitations for discussing the present study's findings is the meager publication of quantitative Brazilian data regarding assistance at home so as to compare the results obtained. ${ }^{10-11,19}$

In relation to the sociodemographic characteristics, the age range of the majority of the women was below that found in the international studies (between 30 and 34 years old $)^{26-30}$ and in another Brazilian study (30-35 years old). ${ }^{10}$ The high educational level is in consonance with another Brazilian study, in which $62.8 \%$ of the women assisted at home had a higher education, ${ }^{10}$ and with one international study ${ }^{23}$ Women with a high educational level tend to have more access to information and knowledge, which allows them to question the currently-dominant model of health and opt for a different locale to give birth to their children, as they believe the home to be an intimate, familiar and safe place, as well as seeking professionals who are trained and qualified for this care. ${ }^{31}$

Due to this mode of care being private, it was to be expected that the majority of the women would undertake paid activity, as this involves the payment of the costs. International studies have also demonstrated that it is women with higher socioeconomic status who opt for this place to give birth. ${ }^{3-4,24,29,32}$ In Brazil, only a small number of home births are attended through the Unified Health System (SUS), being undertaken by the team from the Sofia Feldman Hospital. ${ }^{33}$ Other countries support this type of attendance as an integral part of their Health Systems, as is the case with Holland, ${ }^{4}$ Australia, ${ }^{26}$ Canada, ${ }^{5} \mathrm{New}$ Zealand ${ }^{30}$ and the United Kingdom. ${ }^{29}$

In the present study, the majority of women who chose this place to give birth were primigravidas, which seems to be a Brazilian tendency, ${ }^{10-11}$ diverging from studies undertaken in other countries, in which it was multiparous women who

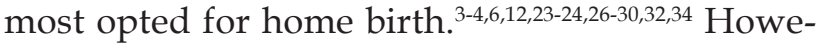
ver, one can observe an increase in the number of multiparous women who opted for home birth (Figure 2), which may result from the satisfaction with the previous experience of birth at home, and from the dissatisfaction of women who gave birth for the first time in hospital.

The increase in the number of home births in this study is in consonance with the worldwide tendency ${ }^{12-13}$ and with the data presented in the Live Births Information System (Sistema de Informação sobre Nascidos Vivos - SINASC), referent to the growth in the number of home births recorded in some Brazilian cities, such as Florianópolis, São Paulo, Rio de Janeiro and Campinas. ${ }^{37}$ This rise may result from the WHO recommendations, which were widely publicized in Brazil, which describe that women's decisions should be respected regarding choice of the place to give birth. ${ }^{8}$ It may also be related to other factors, such as the greater search for autonomy, privacy, individualized attendance, possibility for a higher number of companions, the possibility for early and continuous skin-to-skin contact with the $\mathrm{NB}$, and not to be subjected to unnecessary interventions, given that these are some of the main reasons which motivate women to choose to give birth at home in a planned way. ${ }^{38-41}$

The findings regarding the obstetric behaviors showed that in the home birth, the interventions are reduced and the beneficent practices are implemented, emphasis being placed on water births which, in the hospital ambit, are not frequent. This result differs from the Brazilian obstetric context, as the data from the "Being born in Brazil" study (a hospital-based investigation undertaken in all the regions of Brazil, with a sample of 23,894 puerperal women), revealed that only $5.6 \%$ of the women with normal risk and who gave birth vaginally were not subjected to obstetric interventions during labor and birth, that the lithotomy position was widely used in institutions, passing $90.0 \%$, and that the Kristeller maneuver was undertaken in $36.1 \%$ of the women. ${ }^{17}$

The data demonstrate few changes in fetal well-being, a result evidenced by the stability of the normality of the cardiac frequency during labor over the years. It is important to emphasize that no 
woman in the study was transferred as a result of change in the fetal heartbeat, which differs from some publications s, $^{105-46}$ in which the nonreassuring fetal status was the reason for the transfer.

The respect for the physiology from labor through to birth, and the restricted use of obstetric interventions, may have contributed to the fetal wel1-being and, consequently, to the high rate of clear amniotic fluid. The presence of meconium in the amniotic fluid is discussed little in the studies; however, in one study which compared this variable in different contexts, a rate of meconium in home births of $1.5 \%$ was found, while in hospital, it was $6.4 \%{ }^{29}$

It should be emphasized that preserving the integrity of the membranes may also have favored the fetal well-being and the continuance of the clear color of the amniotic fluid. The rate of amniotomy was similar to that found in international studies, which varied between $5.0 \%$ and $22.4 \% ; 3,5-6,12,34$ however, it was below that found in Brazilian normal birth centers ${ }^{47}$ and in the "Being born in Brazil" study, in which $40.7 \%$ of the women with normal risk are subjected to this intervention during labor. ${ }^{17}$

It is important to stress that no woman had a laceration of the third or fourth degree, as there were no lacerations which compromised the urethral and/or anal sphincter, a data which differs from those of the international studies, in which these lacerations varied from $0.4 \%$ to $7.1 \%$ among women assisted in the home..$^{5-6,26-28,48}$ Emphasis is also placed on the fact that almost half of the women who had a laceration did not need perineal suturing and that the rate of intact perineum was similar to that found in another Brazilian study $(34.8 \%)^{10}$ and above that found in an international study $(14.3 \%$ in nulliparous women). ${ }^{48}$

The undertaking of the episiotomy in just one parturient woman shows that assistance in the home is based in scientific evidence, this being similar to another Brazilian study. ${ }^{10}$ This rate is lower than that found in other countries, where it varies from $2.1 \%$ to $15.0 \% \%^{3,5-6,12,26,29,45,48}$ and is totally discrepant from the hospital environment in Brazil, in which approximately $60.0 \%$ of 'normal risk' women are subjected to episiotomy. ${ }^{17}$

This study indicates a low rate of maternal transfer to hospital, both during pregnancy and during labor, even though the sample is made up of a high number of primiparous women, resembling the case in other countries. This outcome may result from the rigorous protocol for inclusion of pregnant women for attendance by the team. In one systematic review, published in 2014, the rates of transfer varied from $9.9 \%$ to $31.9 \%$, it being the case that among primiparous women this number reached $45.4 \%$, and in the multiparous women, $12.0 \%$, occurring with greater frequency in labor $(8.2 \%$ to $24.1 \%)$, due to slow progression (5.2\% to $9.8 \%) .{ }^{25}$

Regarding complications after birth, delayed expulsion of the placenta was the most common, but no woman needed to be transferred for this reason. Generally speaking, the studies do not present this data. Some indicate the rate of manual removal of the placenta as being between $1.0 \%$ and $1.6 \%,{ }^{6,12,24}$ making it necessary to investigate this issue in the home context.

Hemorrhage was the second-most common complication, and although it occurred in less than $7.0 \%$, it is important to foresee this risk and have medications available so as to contain it, given that, in Brazil, in 2007, in accordance with the International Classification of Diseases, it was the third most common cause of maternal death $(8.0 \%)$, losing only to the hypertensive diseases $(23.0 \%)$ and to sepsis (10.0\%). ${ }^{49}$ One study undertaken in the United Kingdom indicated that the risk of hemorrhage in the postpartum period of women attended in the home is two-and-a-half times less than that of women assisted in hospital..$^{50}$ Other studies present rates which vary from $0.2 \%$ to 9.3\%.$^{5,-6,12,29}$ Hemorrhage in the postpartum period is one of the urgent reasons for transfer, ${ }^{45}$ however, in the present investigation, no puerperal woman was transferred due to this complication, differing from some studies which found a rate varying from $1.0 \%$ to $1.5 \%$ of transfers. ${ }^{3,28}$ The systematic review published in 2014, on the other hand, found even lower rates of transfer ( $0 \%$ to $0.2 \%) .{ }^{25}$

Attention is called to the low percentage of cesareans $(9.9 \%)$ in the total of the sample studied (212) when compared with the Brazilian rate cited above, and with the WHO recommendations that this rate should be below $15 \%{ }^{51}$ This finding was similar to that of a study undertaken in Canada, in which $12.0 \%$ of the primiparous women, and $1.6 \%$ of the multiparous women underwent cesarean section. ${ }^{5}$ The other studies, which do not present the data referent to parity, indicated a rate of cesareans between $2.8 \%$ and $9.2 \% .3,6,12,26-29$ The rates of cesareans found for pregnant women without obstetric complications in hospital births in Brazil (2011 - 2012) were $20.7 \%$ in the SUS and $85.7 \%$ in the private sector, ${ }^{18}$ a mode of care which included the majority of the women in this study.

This study was limited to women attended by a team of autonomous nurses, and the sample refers exclusively to the women who wished to have 
home births. This is, therefore, the group of women who tend to have a privileged socioeconomic status, women with normal obstetric risk, and with specific care (one-to-one) in the prenatal period and during childbirth, which may hinder the generalization of the results to other care contexts.

Among this study's limitations, emphasis is placed on the retrospective data collection, as the failure to completely fill out the medical records limited the analysis of some variables.

\section{CONCLUSION}

There was an increase in the number of attendances over the years. The sample presented a higher proportion of primiparous women, with a high educational level, who undertook paid activity.

The obstetric interventions during labor and birth were rare (particularly episiotomy and amniotomy), and water birth was frequent. Few cases of changes in fetal heartbeat and/or meconial amniotic fluid were observed. The rates of maternal transfer were low and consistent with the literature, few complications were observed in the postpartum period, and no woman needed to be transferred for these reasons. The percentage of cesareans in the samples was $9.9 \%$, far below that observed for women with similar characteristics in Brazil in general.

The assistance provided seeks to respect the principle of comprehensiveness, but fails to meet the principles of fairness and universality of health practices. It is hoped that the results presented constitute evidence for the safety and effectiveness of home birth, and that this may serve as a basis such that this mode of care may be offered to more families, including through the SUS.

The study contributes to the knowledge of some maternal results regarding assistance with home births, as well as of the characteristics of the women who opt for this attendance. Based on these findings, it is considered that planned home births, attended by professionals who are qualified and who have a transfer plan, is a viable option for women who do not wish to give birth in hospital.

\section{REFERENCES}

1. Olsen O, Clausen JE. Planned hospital birth versus planned home birth. Cochrane Database of Systematic Reviews [Internet]. 2012 Sep [cited 2014 Jun 14]; 9: CD000352. Available from: http://almenpraksis. ku.dk/nyheder/oleolsen/Hjemmef_dsel.pdf

2. Olsen O, Jewell D. Home versus hospital birth. Cochrane Database of Systematic Reviews [Internet].
2008 [cited 2009 Abr 16]; 3:CD000352. Available from: DOI: $10.1002 / 14651858 . C D 000352$

3. Johnson KC, Daviss BA. Outcomes of planned home births with certified professional midwives: large prospective study in North America. BMJ [Internet]. 2005 Jun [cited 2008 Dez 11]; 330(7505):1416. Available from: http://www.bmj.com/content/330/7505/1416

4. Jonge A, van der Goes BY, Ravelli AC, AmelinkVerburg MP, Mol BW, Niihuis JG, et al. Perinatal mortality and morbidity in a nationwide cohort of 529.688 low-risk planned home and hospital births. BJOG [Internet]. 2009 Aug [cited 2010 Jan 13]; 116(9):1177-84. Available from: http://onlinelibrary. wiley.com/doi/10.1111/j.1471-0528.2009.02175.x/epdf

5. Hutton EK, Reitsma AH, Kaufman K. Outcomes associated with planned home and planned hospital births in low-risk women attended by midwives in Ontario, Canada, 2003-2006: a retrospective cohort study. Birth [Internet]. 2009 Sep [cited 2010 Jan 13]; 36(3):180-9. Available from: ttp://www.aom.on.ca/ files/Communications/Reports_and_Studies/Birth_ Ontario_Home_Birth_Hutton_Sept_09.pdf

6. Janssen PA, Saxell L, Page LA, Klein MC, Liston RM, Lee SK. Outcomes of planned home birth with registered midwife versus planned hospital birth with midwife or physician. CMAJ [Internet]. 2009 Sep [cited 2010 Jan 13]; 181(6-7):377-83. Available from: http:/ / www.cmaj.ca/content/181/6-7/377.full.pdf+html

7. Wax JR, Lucas FL, Lamont M, Pinette MG, Cartin A, Blackstone J. Maternal and newborn outcomes in planned home birth vs planned hospital births: a metaanalysis. Am J Obstet Gynecol [Internet]. 2010 Sep [cited $2011 \mathrm{Fev}$ 18]; 203(3):243.e1-8. Available from: http://www.ajog.org/article/S00029378(10)00671-X/fulltext

8. OMS (Organização Mundial da Saúde). Maternidade segura: assistência ao parto normal: um guia prático. Genebra: OMS; 1996.

9. WHO (World Health Organization). Making pregnancy safer: the critical role of the skilled attendant. Genebra: WHO; 2004.

10. Colacioppo PM, Koiffman MD, Riesco MLG, Schneck CA, Osava RH. Parto domiciliar planejado: resultados maternos e neonatais. Rev Enferm Ref [Internet]. 2010 Dez [cited 2011 Fev 18]; 3(2):81-90. Available from: http://www.scielo.gpeari.mctes.pt/pdf/ref/ vserIIIn2/serIIIn2a09.pdf

11. Koettker JG, Brüggemann OM, Dufloth RM, Knobel R, Monticelli M. Resultado de partos domiciliares atendidos por enfermeiras de 2005 a 2009 em Florianópolis, SC. Rev Saúde Pública. 2012 Aug; 46(4):747-50.

12. Janssen PA, LeeSK, Ryan EM, Etches DJ, Farguharson DF, Peacock D, et al. Outcomes of planned home births versus planned hospital births after regulation of midwifery in British Colombia. CMAJ [Internet]. 2002 Feb [cited 2010 Ago 24]; 166(3):314-23. Available from: http://www.cmaj.ca/content/166/3/315.full 
13. Lancet. Home birth-proceed with caution. Lancet. 2010 Jul; 376(editorial): 303.

14. Johnson TR, Callister LC, Freeborn DS, Beckstrand RL, Huender K. Dutch women's perceptions of childbirth in the Netherlands. MCN Am J Matern Child Nurs [Internet]. 2007 May-Jun [cited 2010 Ago 24]; 32(3):1707. Available from: http://www.ncbi.nlm.nih.gov/ pubmed/17479054

15. Christiaens W, Bracke P. Place of birth and satisfaction with childbirth in Belgium and the Netherlands. Midwifery [Internet]. 2009 Apr [cited 2010 Ago 24]; 25(2):11-9. Available from: http:/ / www.ncbi.nlm.nih. gov/pubmed/17512100

16. Dahlen HG, Barclay LM, Homer CS. The novice birthing: theorising first-time mothers' experiences of birth at home and in hospital in Australia. Midwifery [Internet]. 2010 Feb [cited 2011 Fev 18]; 26(1):53-63. Available from: http:/ /www.ncbi.nlm.nih.gov/ pubmed/18394766

17. Leal MC, Pereira APE, Domingues RMSM, Theme Filha MM, Dias MAB, Nakamura-Pereira $M$, et al. Intervenções obstétricas durante o trabalho de parto e parto em mulheres brasileiras de risco habitual. Cad Saúde Pública [Internet]. 2014 [cited 2014 Dez 10]; 30(Sup):S1-31. Available from: http://www.scielo. $\mathrm{br} / \mathrm{pdf} / \mathrm{csp} / \mathrm{v} 30 \mathrm{~s} 1 / 0102-311 X-c s p-30-\mathrm{s} 1-0017 . p d f$

18. Domingues RMSM, Dias MAB, Pereira MN, Torres JA, D'Orsi E, PEreira APE, et al. Processo de decisão pelo tipo de parto no Brasil: da preferencia inical das mulheres à via de parto final. Cad Saúde Pública [Internet]. 2014 [cited 2014 Dez 10]; 30(Sup):s101-6. Available from: http://www.scielo.br/pdf/csp/ v30s1/en_0102-311X-csp-30-s1-0101.pdf

19. Koettker JG, Brüggemann OM, Dufloth RM. Partos domiciliares planejados assistidos por enfermeiras obstétricas: transferências maternas e neonatais. Rev Esc Enferm USP [Internet]. 2013 Feb [cited 2014 Jun 14]; 47(1):15-21. Available from: http:/ / www.scielo. br/pdf/reeusp/v47n1/a02v47n1.pdf

20. Feyer ISS, Silva J, Koettker JG, Calvette MF, Burigo RA, Collaço VS. O florescer da vida: parto domiciliar planejado, orientações para gestação, parto e pósparto. Florianópolis (SC): Lagoa; 2009.

21. Koettker JG. Parto domiciliar assistido por enfermeiras [dissertação]. Florianópolis: Universidade Federal de Santa Catarina, Programa de Pós-Graduação em Enfermagem; 2010.

22. Ministério da Saúde (BR). Conselho Nacional de Saúde. Resolução $n^{\circ}$ 466/12. Sobre pesquisa envolvendo seres humanos, Coleção de Leis da República Federativa do Brasil. Brasília: MS; 2012.

23. Cheng YW, Snowden JM, King TL, Caughey AB. Selected perinatal outcomes associated with planned home births in the United States. Am J Obstet Gynecol [Internet]. 2013 Oct [cited 2014 Jun 14]; 209(4):325. e1-8. Available from: http://www.ajog.org/article/ S0002-9378(13)00630-3/pdf
24. Jonge A, Mesman JA, Manniën J, Zwart JJ, van Dillen $\mathrm{J}$, van Roosmalen J. Severe adverse maternal outcomes among low risk women with planned home versus hospital births in the Netherlands: nationwide cohort study. BMJ [Internet]. 2013 Jun [cited 2014 Jun 14]; 346: f3263. Available from: http://www.bmj.com/ content/bmj/346/bmj.f3263.full.pdf

25. Blix E, Kumle M, Kjærgaard H, Øian P, Lindgren HE. Transfer to hospital in planned home births: a systematic review. BMC Pregnancy Childbirth [Internet]. 2014 May 29 [cited 2014 Dez 10]; 14: 179. Available from: http://www.biomedcentral.com/ content/pdf/1471-2393-14-179.pdf

26. Homer CS, Thornton C, Scarf VL, Ellwood DA, Oats JJ, Foureur MJ, et al. Birthplace in New South Wales, Australia: an analysis of perinatal outcomes using routinely collected data. BMC Pregnancy Childbirth [Internet]. 2014 Jun 14 [cited 2014 Dez 10]; 14: 206. Available from: http:/ /www.biomedcentral.com/ content/pdf/1471-2393-14-206.pdf

27. Kennare RM, Keirse MJ, Tucker GR, Chan AC. Planned home and hospital births in South Australia, 1991-2006: differences in outcomes. MJA [Internet]. 2010 Jan [cited 2011 Fev 18]; 192(2):76-80. Available from: https:/ / www.mja.com.au/system/files/ issues/192_02_180110/ken10465_fm.pdf

28. McMurtrie J, Catling-Paull C, Teate A, Caplice S, Chapman M, Homer C. The St. George Homebirth Program: an evaluation of the first 100 booked women. Aust N Z J Obstet Gynaecol [Internet]. 2009 Dec [cited 2014 Jun 14]; 49(6):631-6. Available from: http:// www.readcube.com/articles/ $10.1111 \% 2 \mathrm{Fj} .1479$ 828X.2009.01103.x?r3_referer $=$ wol\&tracking_ action=preview_click\&show_checkout $=1 \&$ purchase referrer $=$ onlinelibrary.wiley.com\&purchase_site_ license=LICENSE_DENIED_NO_CUSTOMER

29. Birthplace in England Collaborative Group. Perinatal and maternal outcomes by planned place of birth for healthy women with low risk pregnancies: the birthplace in England national prospective cohort study. BMJ [Internet]. 2011 Nov [cited 2014 Jun 14]; 343: d7400. Available from: http://www.bmj.com/ content/bmj/343/bmj.d7400.full.pdf

30. Davis D, Baddock S, Pairman S, Hunter M, Benn C, Wilson D, et al. Planned place of birth in New Zealand: does it affect mode of birth and intervention rates among low-risk women? Birth [Internet]. 2011 Jun [cited 2014 Jun 14]; 38(2):111-9. Available from: http:/ / www.researchgate.net/publication/51153408_ Planned_Place_of_Birth_in_New_Zealand_Does_ it_Affect_Mode_of_Birth_and_Intervention_Rates_ Among_Low-Risk_Women

31. Feyer ISS, Monticelli M, Knobel R. Perfil de casais que optam pelo parto domiciliar assistido por enfermeiras obstétricas. Esc Anna Nery. 2013; 17(2):298-305.

32. Van der Kooy J, Poeran J, de Graaf JP, Birnie E, Denktass S, Steegers EA, et al. Planned home compared with planned hospital births in the Netherlands: 
intrapartum and early neonatal death in low-risk pregnancies. Obstet Gynecol [Internet]. 2011 Nov [cited 2014 Jun 14]; 118(5):1037-46. Available from: http:// www.researchgate.net/publication/51732604 Planned_Home_Compared_With_Planned_Hospital_ Births_in_The_Netherlands_Intrapartum_and_Early_ Neonatal_Death_in_Low-Risk_Pregnancies

33. Hospital Sofia Feldman [Internet]. Belo Horizonte (MG): 2015 [cited 2016 May 1]. Available from: http:/ / www.sofiafeldman.org.br/2015/01/05/sofiacomemora-um-ano-de-parto-domiciliar/

34. Wiegers TA. The quality of maternity care services as experiences by women in the Netherlands. BMC Pregnancy Childbirth [Internet]. 2009 May [cited 2010 Jan 13]; 9: 18. Available from: http://www. biomedcentral.com/content/pdf/1471-2393-9-18.pdf

35. Keirse MJ. Home birth: gone away, gone astray, and here to stay. Birth [Internet]. 2010 Dec [cited $2011 \mathrm{Fev}$ 18]; 37(4):341-6. Available from: http:/ / onlinelibrary. wiley.com/doi/10.1111/j.1523-536X.2010.00431.x/pdf

36. Michal C, Janssen PA, Vedam S, Hutton EK, Jonge A. Planned home vs hospital birth: a meta-analysis gone wrong. Medscape [Internet]. 2011 Apr. [cited 2014 Jun 14]. Available from: http://www.medscape.com/ viewarticle/739987

37. DATASUS. Sistema de informações sobre nascidosvivos - SINASC. [cited 2011 Jun 20. Available from: http://tabnet.datasus.gov.br/cgi/deftohtm. exe?sinasc/cnv/nvuf.def

38. Davim RMB, Menezes RMP. Assistência ao parto normal domiciliar. Rev Latino-am Enfermagem [Internet]. 2001 Nov-Dez [cited 2008 Dez 11]; 9(6):62-8. Available from: http://www.scielo.br/pdf/rlae/v9n6/7828.pdf

39. Kruno RB, Bonilha ALL. Parto no domicílio na voz das mulheres: uma perspectiva à luz da humanização. Rev Gaúcha Enferm [Internet]. 2004 Dez [cited 2008 Dez 11]; 25(3):396-407. Available from: http:/ / www. seer.ufrgs.br/RevistaGauchadeEnfermagem/article/ viewFile/4533/2463

40. Medeiros RMK, Santos IMM, Silva LR. A escolha pelo parto domiciliar: história de vida de mulheres que vivenciaram esta experiência. Esc Anna Nery Rev Enferm [Internet]. 2008 Dez [cited 2010 Jan 13]; 12(4):765-72. Available from: http://www.scielo.br/ pdf/ean/v12n4/v12n4a22.pdf

41. Sanfelice CFO, Shimo AKK. Parto domiciliar: avanço ou retrocesso? Rev Gaúcha Enferm [Internet]. 2014 Mar [cited 2014 Dez 10]; 35(1):157-60. Available from: http://www.scielo.br/pdf/rgenf/v35n1/pt_19831447-rgenf-35-01-00157.pdf

42. Lessa HF, Tyrrell MA, Alves VH, Rodrigues DP. Informação para a opção pelo parto domiciliar planejado: um direito de escolha das mulheres. Texto Contexto Enferm [Internet]. 2014 Jul-Set [cited 2014 Dez 10]; 23(3):665-72. Available from: http:// www.scielo.br/pdf/tce/v23n3/pt_0104-0707tce-23-03-00665.pdf

43. Frank TC. Parto domiciliar planejado acompanhado por enfermeira: a experiência da mulher, da família e do profissional [dissertação] Maringá (PR): Universidade Estadual de Maringá, Programa de Pós-Graduação em Enfermagem; 2011.

44. Agência Nacional de Saúde Suplementar (BR). O modelo de atenção obstétrica no setor se saúde suplementar no Brasil: cenários e perspectivas. Rio de Janeiro (RJ): ANS; 2008.

45. Amelink-Verburg MP, Verloove-Vanhorick SP, Hakkenberg RM, Veldhuijzen IM, Bennebroek Gravenhorst J, Buitendijk SE. Evaluation of 280,000 cases in Dutch midwifery practices: a descriptive study. BJOG [Internet]. 2008 Apr [cited 2009 Abr 16]; 115(5):570-8.. Available from: http:// onlinelibrary. wiley.com/doi/10.1111/j.1471-0528.2007.01580.x/epdf

46. Ackermann-Leibrich U, Voegeli T, Gunter-Witt K, Kunz I, Zullig M, Schindler C, Maurer M. Home versus hospital deliveries: follow up study of matched pairs for procedures and outcomes. BMJ [Internet]. 1996 Nov [cited 2008 Abr 16]; 313(7068):1313-8. Available from: http://www.bmj.com/content/313/7068/1313

47. Koiffman MD, Colacioppo PM, Schneck CA, Riesco MLG. Parteiras urbanas em São Paulo 2005-2008. In: Anais do VI Congresso Brasileiro de Enfermagem Obstétrica e Neonatal - COBEON, 2009 Jun 24-26; Teresina, Brasil.

48. Smith LA, Price N, Simonite V, Burns EE. Incidence of and risk factors for perineal trauma: a prospective observational study. BMC Pregnancy Childbirth [Internet]. 2013 Mar [cited 2014 Dez 14]; 13:59. Available from: http://www.ncbi.nlm.nih.gov/pmc/ articles/PMC3599825/pdf/1471-2393-13-59.pdf

49. DATASUS. Óbitos maternos [cited 2012 Mar 7]. Available from: http://tabnet.datasus.gov.br/cgi/ deftohtm.exe?sim/cnv/pmat10uf.def

50. Nove A, Berrington A, Matthews Z. Comparing the odds of postpartum haemorrhage in planned home birth against planned hospital birth: results of an observational study of over 500,000 maternities in the UK. BMC Pregnancy Childbirth [Internet]. $2012 \mathrm{Nov}$ [cited 2014 Jun 14]; 12:130. Available from: http:// www.ncbi.nlm.nih.gov/pmc/articles/PMC3570310/ pdf/1471-2393-12-130.pdf

51. World Health Organization. Appropriate technology for birth. Lancet. 1985 Aug; 326(8452):436-7. 